\title{
On Academic Identification of College English Teacher in Terms of Discipline in Chinese Higher Education
}

\author{
Zeng Zhen \\ ${ }^{1}$ College of International Studies, Southwest University, Chongqin, China \\ ${ }^{2}$ School of Foreign Studies, Guilin University of Electronic Technology, Guilin, Guangxi, China \\ Correspondence: Zeng Zhen, 82 Liuhe Road, Qixing District, Guilin, Guangxi, China. Tel: 86-133-1773-0179. \\ E-mail: joyzeng@163.com
}

Received: September 23, 2019

Accepted: October 4, 2019 Online Published: October 10, 2019

doi:10.5539/hes.v9n4p120

URL: https://doi.org/10.5539/hes.v9n4p120

\begin{abstract}
The paper looked into faculty of Chinese College English (CE)(or CE faculty on the paper), a great proportion of teachers teaching English for all non-English majors in higher education institutions, through analysis of $\mathrm{CE}$ faculty recruitment process, symbiosis of researching and teaching in their performances, as well as their restrained professional development in China higher education. It's demonstrated that disciplinary identity on campus is the premise of being successfully fulfillment of the function of teaching and learning in higher education; CE faculty are supposed to effectively perform their duty in line with their professionals defined and developed by the discipline they are trained by. It's discussed that for securing and protecting the efficiency and academic status of CE and CE faculty, there should be a accrediting process for CE the course accreditation and for $\mathrm{CE}$ faculty with academically educational program awarding degree, which is guaranteed for CE being recognized a important and legalized academic activity serving Chinese higher education as its very first design.
\end{abstract}

Keywords: College English, college English faculty, academic identity, discipline, higher education.

\section{Introduction}

\subsection{Chinese College English (CE) in China}

$\mathrm{CE}$ is a most populous, a compulsory English course defined in the Guidelines of College English Teaching (drafted), 2015 (Wang, 2016), a latest official document on CE in Chinese universities and colleges not just in China higher education (HE), but in the world. There are at least 10 million students attending CE at same semester, and around 60,000 faculties lecturing CE nationwide. On campus curriculum system, CE lasts 2 academic years, 16 credits, taking account $10 \%$ of total credits for eligibly applying bachelor degree (Department of Higher Education [DHE] of MOE, 2007). Such policy has been done in majority universities and colleges in the state till now, leading to the huge attendance for just one course and formulating a huge national testing system: College English Test 4(CET4) College English Test 6 (CET6).

Due to Chinese government keeping on opening up to the outside world, innovation of Belt and Road initiative (Note 1) undertaking especially, additional to the popularity and enhancement of advanced technology, particularly internet development, all are getting Chinese involved into global issues. And English language proficiency, comparatively speaking, is becoming more demanding for competing, no matter at home and outside world in many areas, job hunting included. Training talents with English language proficiency is unprecedentedly concerned under such circumstances and an imminent task to China HE.

\subsection{CE's Crisis}

It's well observed that Chinese learners today, before their entering universities, better trained with English skills, many passed the CET 4 and 6 that have been recognized by employers an eligibility for a job, even eve there would be no possibility to practice such proficiency in future position, or other international English tests, which presenting that learners on campus are supposed to development more than test scoresin terms of their English proficiency. For the changing situation and the increasing demands from both the county and learners in HE, there are some prestigious universities, like Tsinghua University, launching their own reforms under permission of Ministry of Education (MOE) basing on resources they are privilege over others. They are setting up more competitive language programs to take place of $\mathrm{CE}$, or cutting $\mathrm{CE}$ credit ratio in bachelor programs, or reducing 
CE hours and the like(Anonymous, 2012). Such movement hasn't proved its effects, but it is producing a negative signal on $\mathrm{CE}$ that $\mathrm{CE}$ is not able to well serve its learners anymore. Nevertheless, in large extent, $\mathrm{CE}$ is still and would be a main assistant right now in China higher education, serving non-English majors to progress English language proficiency. In order to help learners in universities and colleges to progress their English language proficiency through CE, MOE has launched a series reforms and policies on CE (DHE of MOE, 1999; DHE of MOE,2004; DHE of MOE,2007; DHE of MOE, 2013, May, 22; National Development and Reform Commission and MOE, 2015): increasing investment on in its infrastructure like construction of internet connected lecturing halls, reforming the testing system effectiveness, highlighting the importance of CE faculty with many in-service training programs, etc. in order to improve teaching and learning efficiency. Besides, Scholars and researchers including teachers on CE or the relevance all have spared no efforts to explore the prospects of CE (Ministry of Education and National Language Commission, 2018); MOE, National Development and Reform Commission [NDRC] and Ministry of Finance [MOF] of People's Republic of China, 2013; Wang, 2016; Office of National Medium and Long Term Educational Reform and Development, 2010). On the one hand, it shows the significances of CE in the country, on the other hand, it presents the concerns towards CE from every corner of the state: CE's efficiency and its commitment in Chinese higher education are declining.

\section{Researching Questions}

It's, on those effort and reforms towards CE, explicitly CE crisis should've been explored in its core, not those concerns from outside. The paper intended to initiate an exploration on CE's eligibility in China HE. It's proposed that CE's crisis is originated from its vague identity in HE of China. Due to lack of academic recognition on $\mathrm{CE}$, the very foundation of legitimacy of every academic programs and activities and performance as well in HE, CE faculty, essential effort directly relevant to present CE crisis, is not able to conducts his/her duty professionally with academic concepts and methods as well as knowledge of CE. The contradiction between the increasing demand on talents with English language proficiency and the low performance of CE in HE formulates the researching of this research. This inconsistency haven't been solved successfully so far, though there have been much efforts implemented like that mentioned above.

The paper is going to explore, on the perspective of discipline in HE, the following questions:

What is interpretation of discipline in higher education (HE)?

How is CE faculty profiled?

Is possibility of $\mathrm{CE}$ in $\mathrm{HE}$ constructed a discipline?

What will support CE faculty consistently and effectively assist CE learners with the goal of HE?

In this paper, $\mathrm{CE}$ faculty in this paper mainly refers to teachers serving non-English majors in 4-year Chinese universities and colleges where $\mathrm{CE}$ is usually configured a compulsory subject.

\section{Researching Methods}

The article is taking the advantage of reviewing researching and findings on the relevant issues at home and abroad, besides the documents released by MOE on CE after the foundation of the People's Republic of China. By describing and analyzing the current condition of $\mathrm{CE}$, mainly through analyzing profile of CE faculty, it's concluded that only CE is recognized its academic identity in China HE, in terms of discipline the very foundation of legitimacy in $\mathrm{HE}, \mathrm{CE}$ is able to go through its crisis and CE faculty is able to conduct effectively and academic performance on assisting CE learners, consistent to the goal of HE in large extent.

\section{Literature Review}

\subsection{Perception on Discipline Worldwide}

Looked into various dictionary, the term 'discipline' is generally related to meanings of controlling, punishing, regulating with a set of rules, conventions or rubrics in order to make people in certain communities behave well. "The disciplines characterize, classify, specialize; they distribute along a scale, around a norm, hierarchize individuals in relation to one another and, if necessary, disqualify and invalidate" (Foucault, 1977). Aristotle was the first to introduce a division of knowledge by dividing it into theoretical and practical enquiry (Klein, 2005). This conception was led into a convention of separation of knowledge into more and more specialized divisions. Since modern university appearance, universities and colleges are founded legitimately with factors, and discipline (short form of academic discipline peculiarly used in universities and colleges) is one of them. Lohdal and Gordon (1972) have described disciplinary fields as providing the structure of knowledge in which faculty members are trained and socialized; carry out tasks of teaching, research, and administration; and produce 
research and educational output (Lohdal \& Gordon, 1972). In light with this, discipline is incorporating many element of ordinary perceptions, specially refers to a body of knowledge, which was evolved from tradition of German universities at the very first beginning of the nineteenth century. Stichweh (2001) wrote, "The scientific discipline as the primary unit of internal differentiation of science is an invention of nineteenth century society" (Stichweh, 2001)."It incorporates expertise, people, projects, communities, challenges, studies, inquiry, and research areas that are strongly associated with a given scholastic subject area or college department" (Discipline, 2018, Sep.10). Krishnan thought a researching domain is defined as a disciple, it'd like to be reproductive itself (Krishnan, 2009). It has been argued for a long period that what would be comprised of a legitimate discipline. But some essential features could not be ignored: researching object(like law, society, political); dedicated body of knowledge on the object; demonstrated theories and a set of concepts; terminologies and expertise; and distinctive methodology, addition to the very point of professorial chair, plus responding academic departments and responding professional associations and organizations which are regulated with its routines and conventions under profile of a discipline. With these depictions, there are establishment and development of departments and schools configured in universities in terms of discipline, and faculty of them are profiled, behaving accordingly. Basing on discipline, what faculty is supposed to do in their departments is regulated.

On these claims and definitions, discipline in higher education is perceived a very particular component, which is not only rules people into a certain community in universities or academic institutions the like, but play a fundamental framework assisting university's successful operation: regulating and categorizing concepts of a individual body of knowledge and expertise as content, methods, insights for teaching, learning, researching; even assisting administrations: identifying and classifying departments and schools, as well as evaluating and accrediting a university's legitimacy and reputation representation. Besides, discipline is apparently a rationale for establishment of academic community, which support the members in the community to continually develop their academic activities and practices and confirm their academic status in university, which would assist faculty to get promotion, life tenure-ship, funding programs, and other benefits all connected with discipline relevant.

\subsection{Literatures on CE in Terms of Discipline}

In china, relating $\mathrm{CE}$ to discipline has been considered a refrained topic among the issues in China HE, though ten more years ago, several scholars hypothesized views and exploited on this concern. Xia, Jimei (2002) firstly pointed out CE was not build up in university with its legitimacy or with its academic status. She proposed to build up a discipline of Foreign Language Education in order to relate $\mathrm{CE}$ into a legal discipline in higher education system (Xia, 2002). Xin, Guangqin (2006) argued that CE legitimate status was an very fundamental issue in light with its efficacy in China HE, which supplementing Xia's view. Xin systematically demonstrated a plan on building up discipline of Foreign Language Education. In the article, Xin demonstrated that, on undergoing Chinese disciplinary system, Foreign Language Literature and Applied Linguistics covers language relevant areas, but there is no explicit researching category for CE. CE, in this case, should be categorized, at least, into a sub-discipline, supposed as foreign language education or TESOL/Education popular in foreign countries. Basing on this academic discipline, an academic program with degree granted eligibility is supposed to be created. In short, in Xin's words, Foreign Language Education, the discipline would be posited as a sub-discipline of Foreign Language Literature and Applied Linguistics (Xin, 2006a). Xin's finding was the very first exploration on relating $\mathrm{CE}$ to a discipline. And then, in the same year, Xin published another article in the same year, proposing construction of foreign language education an independent discipline in order to deal with issues of CE faculty. Xin insisted his view on the paper that once foreign language education was recognized as a discipline, foreign language teacher education programs and the related training programs would be profiled with explicit content, objects, knowledge system and developing direction as well, which primarily also offer sufficient preparation for professional development of CE faculty. In terms of this, CE faculty, the profession, would be socially confirmed and possessed with its profession esteem (Xin, 2006b). Almost at the same period, Cai, Jigang (2006) inquired the issue, in his book review, reflect and research, with a individual article titled Is CE capable of be a eligibly independent discipline?[in Chinese] where Cai analyzed that CE faculty would stably develop their professions, which would greatly helpful for CE's status in HEin long runif CE is able to be constructed as an independent discipline (Cai, 2006). Surely, such proposal or analysis on secured CE's legitimate status in Chinese higher education didn't get quick responses, then.

Nearly more than 10 years later, the issue run into researchers again because the worsening condition and crisis $\mathrm{CE}$ today is confronting, addition to the nationally intense call for training talents with English language proficiency for internationally economic competition after many runs reforms (centralized or locally) failed. Cai, Jichang, (2013) again argued the relation of discipline construction with CE crisis in his new article. Cai claimed that HE should construct discipline of Foreign Teaching and Learning or discipline of Foreign Language 
Education and Linguistics as soon as possible in order to eligibly set up academic programs to train and award master and doctor degrees for future CE faculty. He insisted that CE's academic identity in China HE impacts CE faculty's professional level fundamentally, and will restrain CE's efficiency as a whole at the end (Cai, 2013).

From theses hypothesis and concerns, it's explicitly concluded that CE hasn't been recognized a discipline or configured in HE with academic identity, and this directly impacts $\mathrm{CE}$ faculty who is standing in front of $\mathrm{CE}$ learners without any supports in terms of discipline that is perceived as foundational component of HE universally. There is no effective $\mathrm{CE}$, if there is no effective $\mathrm{CE}$ faculty.

\subsection{CE Faculty Depiction in HE of China}

On review the concept of discipline perceived in HE, it's informed that faculty on CE is supposed to conduct his/her performance legitimately and effectively basing on his/her disciplinary profile. Basing on the discipline categorized, like the hypothesis of Foreign Language Education, CE faculty should be capable to get deal with the body of language knowledge to teach and to be learned, the methods relevant and the conceptions around as well. However, the story is different on CE faculty in China HE.

\subsubsection{Blurring Profile of CE Faculty}

There hasn't been a clear profile on CE So far, which confuses and constrains CE faculty's academic performance. On the perspective of discipline in $\mathrm{HE}$ analyzed above, CE faculty, being professional in a profession, is supposed to resemble its discipline profile which might directly support their activities and practices on CE. However, CE faculty in China HE is not supported in the case which would be testified form recruitment process on CE faculty, the very first warrant of securing the efficiency of CE.

Generally, large amount of if not all CE faculty recruited on CE are not screened in line with its disciplinary profile. Of cause, there is a routine: besides holding an academic degree, applicants usually need to give a 20-minute teaching presentation around a text from a CE textbook (it's wired that, in fact, there isn't any knowledge recognized on CE), with aim, subjectively, to inspect applicants oral ability as well as their teaching ability. Then, applicants would be accepted to the position, only when they are able to satisfy with one of the following conditions:

a. Doctors and masters accredited under discipline of Foreign Language Literature and Applied Linguistics (legitimated discipline in all language relevant field in Chinese academic system), but not under any language teaching and learning relevant discipline.

b. Doctors and masters accredited under other disciplines, but with studying or working experience abroad (out of Chinese territory) at least one year, which is considered an proof of being with English language proficiency.

c. Master of Interpret and Translation (MIT) or other professional master. Such diploma is accepted usually in some engineering-based universities, and these applicants should pass CET 4 and 6 or some internationally tests, like TOEFL, with high scores, which would proof applicants' eligibilities of being CE faculty in some extent.

It's clearly informed that there is still impossible to recruit CE faculty with consistent standard across the country, and there isn't academic profile on CE faculty in terms of disciplinary identity. As it's analyzed before that a discipline is perceived as a branch of academic studying/knowledge. CE faculty severs learners certain knowledge. In the case, here comes the inquiry that what would CE teach in $\mathrm{CE}$ and how would they teach, if CE faculty hasn't been profiled clearly is not identified and recognized its discipline category. Besides, there is an increasing view on CE faculty, "seemingly, being able to speak English language, being able to lecture CE", which is not only challenging the eligibility of the position in HE, but is against the essential concept of construction of modern university: teaching and researching synergy. And a worsening fact towards CE faculty is that some faculty, from the requirement of $b$ and $c$ stated above, are not trained with any language relevant programs academically, their capacity on English has never possibly been guaranteed even they're experienced in a foreign country or pass any English tests (there has been any English tests dedicated toward a profession, accrediting English language proficiency).

Due to this, concerns coming from top education ministration on quality of faculty serving CE stipulate national reforms on improving quality of CE faculty. It's stressed that the current situation of CE and new task in its round highly call on reforms on CE; and the reforms would spare no efforts on training CE faculty with lofty education ethic, professional expertise; vigorously developed in all aspects (Liu, Guiqin, then vice direction of department of higher education under MOE, 2012). Considering the professional expertise supposedly involving in CE, which is a key component directly relating to a discipline, there would impossibly be any effective plans if there is not eligible CE faculty recruited today in HE, because the professional expertise on CE haven't categorized and recognized. 


\subsubsection{CE Faculty 'Double Faces' Life in HE}

To CE faculty in Chinese HE, in long run, is observed to get deal with two different tasks: teaching CE in the daytime, researching at night on other topics rather than CE - 'double faces' life. And they are incapable of fulfilling this 'double faces' life well, neither of them.

On the one hand, to majority of CE faculty, researching is not considered a necessity. This can be testified through the publications and academic engagement produced by CE faculty of China HE. Hao, Chengmiao (2015) looked into all publications of CE faculty till then when his researching was conducted, and he found that there are about 900 universities and colleges serving undergraduates CE across the country, and tens of thousands of CE faculty engaging. But only 1 piece of article was published by each of the CE faculty in every five year.It's verified that almost if not all CE faculty publish only one paper on thoseCSSCI journals and the like influential journals in his/her life-long careerin China HE (Hao, 2015). Cai, Jigang (2013) argued the problem-- academic capacity of CE faculty, by using a survey result he once conducted to present the worsening condition, on counting CE faculty's academic activities and researching achievementsin one key Chinese university before and after 10 years. With statistically inspection on publication (included all publication, not limited in language journals, in recent 3 years (2008-2010), it's found that, there were only 62 publication, 0.2 piece of article for each one averagely. Cai inferred that the situation would be worsening in ordinary universities and colleges, for it didn't change a little in a key university when comparing its situation before and after ten years (Cai, 2013). Besides, Cao, Juexin and Zhang, Bowei (2016) surveyed on teaching capacities towards CE faculty in 5 provincial universities located in Changchun, China. It's found that CE faculty over these universities, as a whole, did not academically posses scholarly knowledge of CE, and hardly satisfied with 'basic line' of teaching and researching capacity required on faculty in university (Cao \& Zhang, 2016). Seemingly, CE faculty is incapably on researching. Nevertheless, it's a fact and trend as well, that more CE faculty hold higher academic degree, like doctor and master degree. Wang, Haixiao (2009) surveyed on this topic, and found that among 21,065 CE faculty inspected (form 453 universities and colleges nationwide), there were $1.5 \%$ of them holding doctor degree, and $60.1 \%$ of them master degree, which was highly increased compared with that in year of 2001(0.3\% and $21 . \%$ for each category) and $1.28 \%$ and $53.5 \%$ in 2008 (Wang, 2009). And CE faculty, as a position configured in China HE, prefers those with doctor degree, better with linguistic relevant training experience. It's implied that degree doesn't help CE faculty conduct both researching and teaching on CE, if programs with degree is not dedicated to knowledge and expertise of CE.

On the other hand, CE faculty, with higher degree other than on CE, even graduated from linguistic related programs, like foreign language literature configured in Chinese academic discipline system, which little or seldom stressing language teaching and learning, haven't been academically trained on both researching and teaching on $\mathrm{CE}$ as well that is dedicatedly serving non-English majors through $\mathrm{CE}$. This very situation initiates a special context for specific demands on CE faculty's conception and performance in teaching and researching $\mathrm{CE}$ in HE. In short, $\mathrm{CE}$ is an academic area under a discipline category, covering a body of knowledge and expertise dedicated. It's, in terms of academic discipline, explicitly interpreted that researching on $\mathrm{CE}$ is originated from and serve a certain an academic discipline, and a researcher (CE faculty supposed) would performance his/her work in academic way: explicit concepts, methods, inquiry models etc.

In short, without academic discipline recognition, CE faculty has to perform their duty dividedly, even mindlessly: teaching $\mathrm{CE}$ in daytime; researching something other than $\mathrm{CE}$, but they are unable to do both of them well.

\subsubsection{CE Faculty Fails on their Professional Development}

Faculty's professional development is a hot topic and attention of all concerns. It's reasonably inferred that faculty's capacity, learning, teaching, researching and the like, should be recognized as the core of all kinds of reform, because faculty's capacity of interpretation and fulfillment on any reform are the priority and foremost factor towards efficiency and success of any programs. In other words, there wouldn't be excellent students without excellent teachers. In China, the concern on teachers is intense too. It's claimed, according to researching on the field, that the professional development of CE faculty has been highly developed in China HE, in the second developing stage, at least, because the academic organizations, regular seminars among the faculties and dedicated journals are operated well and satisfied by participants (CE faculty). It's indicated that Chinese foreign teacher education is on developing stage (Wen \&Ren, 2010). However, these scholars' assertion seems unable to explain the crisis of CE confronting if CE faculty has been developed well in their career.

Guidance of Chinese College English Teaching 2015(short in Guidance 2015 below), a centralized document on CE promulgated in China HE nowadays, defines CE a course identity. However, exploring the terms of 
'discipline', 'major' and 'course', it's clear that 'course' services 'discipline' or 'major', assisting learners to master his/her disciplinary expertise and knowledge within a certain academic program. 'Course' is constructed under a certain 'discipline' or 'major'. Guidance 2015 doesn't specialized CE towards a certain academic major, but for all non-English major learners, which indicates a broad and blurring goal for CE. It's unlike ESP (English for Specific Purpose) or EAP (English for Academic Purpose) and other language programs widely implemented worldwide, which explicitly serve dedicated learners with dedicated purpose. In Guidance 2015, CE is generally identified a course with blurring connotation on its goal, its learners, methods as well, which can't be recognized its profession. It's perceived that profession is referred to certain learning experiences or positions which are conducted by a group of people specialized in and with certain necessary knowledge and expertise, relevant with discipline in academic sense. Besides, the Teachers Law (National People's Congress Standing Committee of China, 1993) regulates that teachers are professionals conducting educational activities and practices. Being professionals, teachers must master expertise of the profession. On such condition, the professional expertise haven't been recognized and described or profiled explicitly into profession of CE faculty today because currently, most if not all faculty, before entering CE classroom, didn't master expertise on CE through their educational experiment, even some of them being awarded with doctor degree certificate. In short, current CE faculty is not able to be recognized as professionals in all in its all rounds.

In summary, exploring the situation of current $\mathrm{CE}$ faculty in terms of its recruitment process, effects of its academic performance and its professional development, it's argued that, in terms of discipline, CE faculty hasn't been academically trained and prepared well for his/her appearance in front of learners in CE lecture hall. Consequently, it would be difficult to expect any efficient improvement or change resulted from various movements and reforms on CE faculty as well CE. It's discipline identity, basic and core of CE and CE faculty as well, that legitimately constructs and functions $\mathrm{CE}$ in China HE, which is the fundamental factor on low efficiency of CE faculty.

\section{Discussions}

\subsection{Construction and Recognition of CE's Legitimacy in China HE System in Terms of Discipline}

\subsubsection{It's Well Prepared to Construct Foreign Language Education in Chinese Academic System Supporting CE's} Legitimacy in HE

On academic inquiry of CE in China HE sysytme in terms of discipline, it's long been discussed and concerns, like reviewed previously. The first relevant publication delivered by Professor Xia, Jimei (2002)who firstly related the problems (that mentioned above, about CE faculty the likes) on CE to its discipline identity, though Xia didn't, then, further evidenced and proposed a discipline category covering $\mathrm{CE}$ or a discipline of $\mathrm{CE}(\mathrm{Xia}, 2002)$. But, Xia's view was noticed and some researchers invested their interests on this view on CE and its presentation in China HE in succession. The efforts on the issue leadto a formation of theoretical conception on $\mathrm{CE}$ in terms of discipline, Foreign Language Education. It's substantially outlined by the work of two scholars-Wang, Wenbing and Li, Ming (Wang \& Li, 2017; 2018). From 2016-2018, Wang, Wenbing and Li, Ming, targeting crisis on CE, published articles inquired and explored CE crisis, and innovatively constructed an academic term as well as its academic interpretation on CE issues in order to respond and resolve CE crisis from its root. The two researchers believed that foreign language teaching and learning, the term, could not be used to describe the broad scope of language and its complicated nature under Chinese contexts. They proposed and constructed Foreign Language Education (first appeared in article of Xin, Guangqin (Xin, 2006a), a discipline term proposed to cover and connote all language issues in China HE. In the view's of Wang, Wenbing and Li, Ming, Foreign Language Education is an academic discipline, covering all language educational processes, comprising of its philosophy and conventions as well presenting and interpreting goals, policies and regulations relevant to foreign language education under HE, outlining its curriculum, textbooks, method and researching topic as well etc.11 key researching topics (Wang \& Li, 2018). Wang and Li listed 11 essential topics, among which language teaching and learning is just one among the others, instead of be recognition or definition as a course, only individual training activities without its relevance to disciplinary category. The two scholars stressed that the Foreign Language Education, in their words, is a scholarly area around all aspects of foreign language education-language teaching + learning (Wang, and Wang 2018). Wang and Wang further enhanced Xin, Guagnxin' view (Xin, 2006a) and their proposal of discipline of Foreign Language Education (Wang \& Li, 2018) is substantially depicting CE's definition, goal, researching topic, with which the implicit profile of CE is emerging.

So far, over decades of efforts invested on CE and concerns of stakeholders as well as the huge social impact of $\mathrm{CE}$, all are boosting the concept of relating $\mathrm{CE}$ to discipline-Foreign Language Education, though the consensus 
does still not yet come up due to various researching approaches and angles. Nonetheless, the conception of Foreign Language Education has already been theoretically proposed and analyzed with researchers on CE. Particularly, the proposal from researches of Xin, Guangqin (2006a) and Wang, Wenbing and Li, Ming (2016, Oct.18, 2017, 2018) would be considered as a pioneer innovation in the context of higher education in terms of academic discipline. Beside, the efforts in light with theory construction, considering other factors comprised of a discipline, there are more encouraging preparation for construction of Foreign Language Education. One factor is contribution of Chinese centralized power forces. With every centralized supportive efforts, like dedicated reforms on CE initiated top-down more than a decade, many model universities and colleges practicing various reforms on CE consistent to documents issued by top administration institution. And CE has been being operated and developed with its own particular management, operational system, industrious activities and researching journals in and outside campus, which all assist to create its special status socially and academically. Most important issues for securing and promoting its development are: one is that $\mathrm{CE}$ is under the supervision of National College English Supervision Committee commissioned by MOE, indicating its official status while CE also is assisted directly by local supervision committee on $\mathrm{CE}$ that is comprised of regional universities and colleges; another issue is CE got its academic organizations, such as, Chinese Committee on Researching English Language Teaching and Learning and Foreign Language Teacher Education and Professional Development build up in 2005, indicating possibility of regularly academic activities around CE. And the relevant journals created soon after the establishment of these organizations, as well as thousands of millions articles publicly published every year around issues on CE, which could be verified through searching CNKI, a Chinese scholarly publication data base most widely used among Chinese researchers. Formation of organization, regular academic seminars and conferences, dedicated journals, indicated an academic community well organized nationwide (Wen \& Ren, 2010).

All these facts and efforts indicate that it's a trend to promote and configure the disciplinary identity of CE in HE, no matter the term-discipline, is avoided to mention among current academic mainstreams on the field. CE recognized or categorized into a discipline is the need and requisite for $\mathrm{HE}$ on training talents with English language proficiency.

5.1.2. CE Faculty, Trained Under Discipline of Foreign Language Education, Perform Their Duty Academically and Effectively

Today, Knowledge is completely changed its presentation, not exclusively belonging to or offered in a certain institution and organization. In a broadening sense, knowledge is available through internet universally once the network is activated, which is completely attacking, the traditional perception of researching and teaching nexus in higher education system because learners are not learners before as they are readily accessing to knowledge everywhere and anytime, and even, learners realistically could be able to being a producer of knowledge in the technology-based world. This technology-promote knowledge interpretation presents a more complicated situation on $\mathrm{CE}$ because language teaching and learning is unable to be refrained in Chinese classrooms and schools, being a pure skill trained. Instead, knowledge of foreign language, intimately woven with internet and other advanced technology, are emerging and reconstructed co-operatively in its academic domain (linguistic theories, SLA researching, cognition recognition on language development etc.). Therefore, the conventional utilization (not only a skill used for translation and interpretation, but a cognitive capacity on routine life due to the English language permeation through internet in china nowadays), which just might be another factor involving with creation of a new discipline, like emerging Foreign Language Education. Arimoto (2011),on perspective of knowledge society, has developed the idea of researching-teaching-studying(R-T-S) nexus in light with "relationships between social reform and the academic profession with a focus on a vision of the academic profession in the changing relationship between society, the government, the university, and knowledge..." (Arimoto, 2011). CE faculty are demanded to be capable with both knowledge of language pedagogy and knowledge of technology for the feature of the new era initiated on knowledge-base technology invention, instead of instructing learners in old way-memorizing vocabulary, translating a passage or an text, etc. The urgent need emphasize the symbiosis of researching and teaching on CE. Shin,JungCheol (2011) proposed that researching can and should be defined more broadly to facilitate the integration of teaching and research(Shin, 2011). Brew and Boud (1995) viewed research is not just about outputs, and it is also about the process of discovering information (Brew \& Boud, 1995).

This changed trend indicates that many more illustrations on researching and teaching nexus appearing from different perspectives, the most of it in on the understanding of knowledge and forms of its presentation; learner and learning; function of university etc. Scott (2002) stated, "In a 'knowledge society' all students -certainly all graduates - have to be researchers. Not only are they engaged in production of knowledge; they must also be 
educated to cope with risks and uncertainties generated by the advance of science"(Scott, 2002). Under currently social life, higher education is not exception and even greatly impacted by tech-innovations and need to produce more. Responding this, CE faculty today, under the proposed foreign language education, would quickly represent the new knowledge developing trend, language knowledge as their core, through researching and teaching nexus defined in its discipline, leading to a creative performance responding both to their disciplinary profile and to their learners demand. And in turns, CE faculty would initiate new innovations, in terms of discipline, through their interpretation during practice their roles with concept of symbiosis of researching and teaching, enhancing and promoting CE its function and its legitimacy as well in HE.

In terms of proposed Foreign Language Education, though it counterpart--TESOLE/ TFL/TSL (Teaching English to Speakers of Other Languages/Teaching Foreign Languages/Teaching Second Languages) programs secured its academic identity in higher education institution across the world for quite a period, CE faculty would be greatly encouraged on their teaching and researching, as well as learning activities and practices, which are basics woven into a formation of universities and colleges. This finally works on CE learners with CE faculty's effective performance basing on their academic researching in the field.

\subsection{Supports on Constructing CE's Disciplinary Identity and CE Faculty's Academic Performance Well in China $H E$}

\subsubsection{Establishment of an Academic Programtowards Candidates of CE Faculty}

In line with discipline, Foreign Language Education, it's suggested there should be an academic education program configured in China HE, in order to secure the academic knowledge construction for those future CE faculty. Simply speaking, employees, particularly academics staff would be recognized and esteemed from disciplines where they're categorized academically. With academic preparation, faculty would continually and implicitly make every effort to improve their disciplinary awareness, and ensure explicitly their status as well as vales in higher educational system: formulating their dedicated community, secure their researching and teaching boundary, construct their effective performance format, as well as their authority and power over the universities and colleges (Henkel, 2000). This profession awareness and valued assessed basically standing on the discipline CE faculty configured. Briggs (2007) interpreted 3 relevant concepts on professional identity towards employees: "professional values (What I profess), professional location (The profession to which I belong) and professional role (My role within the institution)" (Briggs, 2007). It's indicated that if CE faculty effectively serves CE, they need to be aware of the relation between the position and their professional identity. Additionally and importantly, CE faculty's professional identity is the rooting base for initiating their professional development plan.

CE faculty, this profession, is not secured personally or recognized byan organization, but secured by a community including members sharing common interests with specialized expertise. Faculty's action in its professional community indicates that their common interests and specialized expertise are formulated and supported under and defined in terms of systematically processing (like the factors necessary for comprising of a discipline discussed above) and is legally accepted by the whole society. Therefore, professional identity once defined, in turns, presented employees' interpretation on their profession: what to do, how to do, and where to do relevantly. On this condition, CE faculty need an academic educational program which construct the very conceptions for the professional identity and profession awareness before they're facing their learners, a well prepared program. Such formal educational programs entitle to award academic certifications have been prosperous internationally. In foreign countries, TEFL(Teaching English as a Foreign language)/ TESOL(Teaching English to Speakers who) are the mostpopular program. All applicants, applying English language teaching for non-English natives, are needed to get certificate or degree of this discipline. On TESOL official website, it's found that there more than 400 universities and colleges offer and award TESOL certificates and academic diplomas in just United States and Canada. And all prestigious universities and colleges offer educational program on TESOL/TEFL with master and doctor level (Cai,2013).

Responding to China's fast development with highly demands of participating into global issues, HE needs to restructure its conception on $\mathrm{CE}$ status in terms of discipline. It's should be confirmed that $\mathrm{CE}$ is not a marginalized subject or course for formatting a comprehensive university, instead, a functionally operating in order to assist learners to be talents with language proficiency required by the country. Beside, considering on features of knowledge-based society, the CE faculty should be academically educated and developed with not only systematically and scientifically constructed knowledge and expertise in the field, but a explicit recognition and conception on professional identity and profession profile in terms of disciple, which only rely on a educational programs entitle to award certifications and diplomas. 


\subsubsection{Initiating an Academic Quality Certification and Accreditation Process}

Even there isn't any educational programs dedicated to CE faculty, there is a process conducted in Chinese universities and colleges on accrediting all staff, both lecturers and researchers working in HE, in order to secure their eligible identity. This process awards Certification on Faculty of Universities and Colleges, which is legalized by the Teacher's Law (National People's Congress Standing Committee of China,1993) and the Law of Higher Education(National People's Congress Standing Committee of China, 1998). Accordingly, both laws regulated that all faculty responsible for lecturing and educating learners in HE need not only professional expertise and knowledge categorized under relevant disciplines, which is proved by an academic diploma, but is certified experience on satisfying the professional routine and qualifications which is proved with the special accreditation process. Certification on Faculty of Universities and Colleges is used to accredit faculty eligibly working in HE. However, this legal priority doesn't work realistically in Chinese HE. Generally, it's observed, in fact, academic achievement and the relevant evidence is still the primary determiner on recruiting a new faculty, academic diploma working in all universities and colleges. The Certification on Faculty of Universities and Colleges, regulated by laws, would be delivered after the newly recruited faculty completing a dedicated training program for novices (Ye, 2011; Zhen, 2013). It's indicated the accreditation process for accrediting the quality and eligibility of working in HE doesn't a prerequisite of being a faculty in China HE. And it doesn't work as a screening step of a securing step assisting and guaranteed the quality of faculty on HE, CE faculty is no exception in this sense. It's apparently informed that $\mathrm{CE}$ faculty, most if not all, serve CE with any evidence on their qualification, which could be recognized as the core reason why $\mathrm{CE}$ is facing its crisis-unqualified actions leading to dis-function of CE. It's urgent to restructure the conception of CE faculty, particularly on their quality guaranteeing and certifying process, in terms of discipline.

Investigating the issue around the world, it's presented that, creation of Certification of CE faculty is a widely practice. IEP (Intensive English Program ), taking as an example, is a relevant counterpart against CE in China, constructed in US higher education institutes. Though the context of establishment of IEP is quite different from Chinese CE, it has been operated successfully through its dedicated accreditation process. first, teacher on IEP would past the courses or programs on getting the qualification of entering the field, verified by relevant master diploma of course certification . Most if not all teacher on IEP got educational experience on teaching IEPs and relevant teaching areas, who are educating English in other countries other than in US (Olando, 2016). Besides, for securing the quality of IEPs, universities and colleges take IEPs program into its comprehensive system of quality accreditation. IEPs program functionally is operated under specialized organizations, like TESOL (Teaching English as Second Language), AAIEP(American Association of Intensive English Programs), and UCIET(University and College Intensive English Programs), which initiate its teaching standards and performance format, as well as its management. IEPs create its assessing process basing on standards or guiding items delivered from AAIEP and UCIEP.AAIEP and CUIEP co-work to secure IEPs program in universities and colleges across Unites States, as well as the teachers status. December, 14, 2010, then president Obama approved a law for accrediting English language training programs (generally Law for Accreditation) (Editorial, 2016). It's legalized that all IEPs programs should go through the accreditation processes from a commissioned organization by Department of Education in US. Currently, CEA (The Commission on English Language Program Accreditation) and ACCET (Accrediting Council for Continuing Education and Training) are authorized organizations to run the accreditation processes (Szasz,2010).

Exploring such global model, IEPs here just one case among accreditation processes on securing English language program, it's suggested to create a dedicated process for accredited CE faculty a position with legitimacy in Chinese higher education system-Certification of CE faculty. This accreditation would be consistent with academic discipline, profiling $\mathrm{CE}$, and reflects necessary professional teaching standards and its performance format candidate $\mathrm{CE}$ faculty need to recognize and effectively apply into their routine lectures, which would be used to assess the teaching quality, prompt faculty's profession status and build up teacher education standardized system, as well as, in turns, enhance the validity of the certifying process (Xiong, 2008). Nowadays, there is a innovation conducted in language field, giving an sample for developing a dedicated accreditation process toward faculty on CE. In 2015, a policy was issued from Chinese top administration, regulating a national test for awarding teaching certification in terms of teachers' quality. It's explicitly stated that all candidates applying teaching English in junior or senior high schools should first pass the test in order to get the certification. This is a reform directly towards English teachers, in terms of professionalizing English teaching and its professional development. The innovation is aiming to reform the old accreditation process for securing and promoting quality of teacher in English teaching position, which has been criticized for long time in light with its life-long validity. This is a positive movement responding to international accreditation process for 
English teachers, as well as the teaching itself. It's very first trial movement on English programs in China in terms of discipline, though its target hasn't been towards CE faculty.

Summarized from above illustration, a dedicated accreditation process is appealing that would help to certified and verified $\mathrm{CE}$ faculty, making sure the novice educated with enough sufficient preparation before they enter $\mathrm{CE}$, in terms of discipline which is just the content future $\mathrm{CE}$ faculty are educated through an academic program with diplomas. And the certification would not be with life-long validity in line with the conception about knowledge-based society. It's proposed a certification CE faculty, as well as a accreditation process for CE itself, in terms of discipline, both with temporary validity instead of being life-long valid. Therefore, the validity the certification would be enhanced or eliminated according to faculty's professional development during their whole career on CE. Of course, the continuously researching in aspect of the discipline, supports from top authorities, both with policies and financing programs, as well as the management of HE on its own sake would give support for this innovation of foreign language education in case of CE.

\section{Conclusion}

In the knowledge-based society, learners in $\mathrm{HE}$ are supposed not only to master knowledge written down on textbook, but to relate the knowledge to their life and work successfully, and even to create some new knowledge basing on it potentially. English language is compelling knowledge as well as productive knowledge, which increasingly assist learners to competitively engage at global issues. China Higher education bears it in mind when function its goal and construct its discipline system with the trend, CE included in the case. But, on the perspective of discipline, $\mathrm{CE}$ is confronting its crisis that refrains its function on serving learners in $\mathrm{HE}$ effectively. By analyzing the $\mathrm{CE}$ faculty profile in $\mathrm{HE}$ in their recruiting process, their 'double faces' routine performances, as well as their in--service training programs and its effects, it's informed that CE faculty is not trained academically and supported well in order to fulfill the goal of CE in HE because CE isn't configured in HE like other academic programs, curriculum and courses relevant etc. that based on certain discipline category. Disciplinary identity is determiner of legitimacy of $\mathrm{CE}$ as well as CE faculty in $\mathrm{HE}$.

With demonstration and illustration, it's informed that CE in China is prepared well to be conceived a discipline, Foreign Language Education, which has been proposed and argued by some Chinese researchers and assisted by efforts in its own sake; CE faculty, in the case, is able to be prepared academically and trained well basing on Foreign Language Education before they enter CE lecturing hall, in front of CE learners with systematically categorized knowledge, methods, concepts and the like comprising a discipline, which would result in, at least, a professional and academic performance on the duty. Being the parameter in CE and CE learners' success with English language proficiency, CE faculty, for their professional development, is proposed to be supported by Foreign Language Education in their educational preparation tour before taking the position, and develop professionally after entering the career by periodically certification and accreditation process in order to secure CE faculty's lifelong learning as a whole responding the fast changing world and the goal of HE, and assist and enhance its professional development academically and effectively.

\section{References}

Annala, J., \& Mäkinen, M. (2011). The research-teaching nexus in higher education curriculum design. Transnational Curriculum Inquiry, 8(1), 3-21.

Retrieved from http://citeseerx.ist.psu.edu/viewdoc/download?doi=10.1.1.466.7427\&rep=rep1\&type=pdf

Anonymous (2012). Tsinghua University English Proficiency Test Reform (2012), Firstly Conducted In December This year. Retrieved from http://page.renren.com/600806598/channel-noteshow-871418401?pid=600806598

Arimoto, A. (2011). The changing nature of academic work from an international perspective. Higher Education Forum, 8, 1-22.

Belcher, D. (2007). A bridge too far?. TESOL Quarterly, 41(2), 396-99. https://doi.org/10.1002/j.1545-7249.2007.tb00066.x

Borg, S. (2010). Language teacher research engagement. Language Teaching, 43(4), 391-429. http://dx.doi.org/10.1017/S0261444810000170

Brew, A., \& Boud, D. (1995). Teaching and research: Establishing the Vital Link with Learning. Higher Education, 29(3), 261, 268-9. https://doi.org/10.1007/BF01384493

Cai, J. G. (2006). College English Teaching: Review, Reflect and Research. Shanghai, China, Fudan University Press. 
Cai, J. G. (2013). On College English Crisis and its Discipline concern. China Univeristy Teaching, 2, 10-14.

Cao, Y. X., \& Zhang, B. W. (2016).The Investigation and Analysis on University Teachers' Abilities to Teach. Journal of Northeast Normal University(Philosophy and Social Sciences, 2, 207-213.

DHE of MOE (1999). College English Teaching Syllabus 1999(revised). Higher Education Press and Shanghai Foreign Language Education Press,(2nd Eds.).

DHE of MOE (2004a). College English Course Teaching Requirements 2004( trial), in document of No.1 (2004). retrieved from MOE portal. Retrieved from

http://www.moe.edu.cn/publicfiles/business/htmlfiles/moe/moe_734/200408/729.html

DHE of MOE (2004b). Announcement On Conducting Experimental Trails on College English Teaching. In document of No.21. Retrieved from http://www.moe.gov.cn/s78/A08/s4532/201001/t20100129_93342.html

DHE of MOE (2005). Announcement on recommending new terms of members for TeachingAdvisory Board in Tertiary Education under MOE. Retrieved from http://www.moe.gov.cn/srcsite/A08/s7056/200504/t20050418_124825.html

DHE of MOE (2007). College English Course teaching Requirement 2007 (revised). Foreign Language Teaching and Research Press.

Editorial (2016). The impact of accreditation on Intensive English Programmes in the US. ICEF Monitor. retrieved from its portal. Retrieved from http://monitor.icef.com/2016/01/the-impact-of-accreditation-on-intensive-english-programmes-in-the-us

Ellis, R. (2010). Second language acquisition, teacher education and language pedagogy. Language Teaching, 43(2), 182-201. Retrieved from http://dx.doi.org/ http://dx.doi.org/10.1017/S0261444809990139

Erlam, R. (2008). What do you researchers know about language teaching? Bridging the gap between research and language pedagogy. Innovations in Language Learning and Teaching, 2(3), 253-267. https://doi.org/10.1080/17501220802158958

Foucault, M. (1977). Discipline and Punish: The birth of the prison. Trans. Alan Sheridan. New York: Vintage. (Translation of: Surveiller et punir; naissance de la prison. [Paris]: Gallimard, 1975.

Hao, M. C. (2015). Confusion and Construction of College English as a Discipline: An FLEP Perspective. Language Education, 1, 27-34.

Henkel, M. (2000). Academic Identities and Policy Change in Higher Education. London: JessicaKingsley.

Humboldt, W. (1810). Über die innere und äussere organisation der höheren wissenschaftlichen anstalten in Berlin. In E. Anrich (1959) Die Idee der deutschen Universität (pp. 375-386). Darmstadt: Hermann Gentner.

Klein, J. T. (2005). Humanities, Culture and Inter disciplinarity / The Changing American Academy, New York: State University of New York Press, pp. 15.

Krishnan, A. (2009). What are Academic Disciplines? Some observations on the Disciplinarity vs. Interdisciplinarity debate. ESRC National Centre for Research Method. NCRM working paper series. Retrieved from http://www.forschungsnetzwerk.at/downloadpub/what_are_academic_disciplines2009.pdf

Liu, G. C. (2012). Highly boosting College English Teaching Reform for its great effects. Foreign Langauge Teaching and Research, 2, 280-282.

Lodahl, J. B., \& Gordon, G. (1972). The Structure of Scientific Fields and the Functioning of University Graduate Departments. American Sociological Review, 37(February), 57-72. https://doi.org/10.2307/2093493

McDonald, M., Badger, R., \& White, G. (2001). Changing values: What use are theories of language learning and teaching?. Teaching and Teacher Education, 17(8), 949-63. https://doi.org/10.1016/S0742-051X(01)00042-7

McDonough, K. (2006). Action research and the professional development of graduate teaching assistants. The Modern Language Journal, 90(1), 33-47. https://doi.org/10.1111/j.1540-4781.2006.00383.x

Ministry of Education and National Language Commission (2018). China's Standards of English Language Ability. Retrieved from http://www.moe.gov.cn/jyb_xwfb/gzdt_gzdt/s5987/201804/t20180416_333331.html

MOE, NDRC \& MOF (2013). An Announcement on launching Revitalization Plan of Tertiary Education in 
Mid-West Area of China(2012-2020), in document of No.2(2013). Retrieved from http://www.moe.edu.cn/publicfiles/business/htmlfiles/moe/s7056/201303/148468.html

National Development and Reform Commission and MOE (2015). Announcement on National Enrollment Plan of Higher Education. Retrieved from http://old.moe.gov.cn/publicfiles/business/htmlfiles/moe/s7050/201504/186363.html

National People's Congress Standing Committee of China (1998). Higher Education Law of People's Republic of China 1999, retrieved from Ministry of Education old portal. Retrieved from http://old.moe.gov.cn//publicfiles/business/htmlfiles/moe/moe_619/200407/1311.html

National People's Congress Standing Committee of China(1 993). Teachers' Law of People's Republic of China 1994 . retrieved from Ministry of Education portal. Retrieved from http://www.moe.gov.cn/s78/A02/zfs__left/s5911/moe_619/tnull_1314.html

Office of National Medium and Long Term Educational Reform and Development (2010). National Medium and Long term Educational Reform and Development Outline 2010-2020.Retrieved from http://old.moe.gov.cn/publicfiles/business/htmlfiles/moe/info_list/201407/xxgk_171904.html

Orlando, R. (2016). Teaching English in U.S. University IEP programs. TESOL Press, 2016(1). http://www.tesol.org/docs/default-source/books/14084_sam.pdf?sfvrsn=2

Scott, P. (2002). Let's stop trying to separate the inseparable. Exchange, 2, 27-28. Retrieved from www.exchange.ac.uk

Shin, J. C. (2011). Teaching and Research Nexuses Across Faculty Career Stage, Ability and Affiliated Discipline in a South Korean Research University. Studies in Higher Education, 36, 485-490. https://doi.org/10.1080/03075071003759052

Stichweh, R. (2001). Scientific disciplines, History of. In N. J. Smelser \& P. B. Baltes (Eds.). International Encyclopedia of the Social and Behavioral Sciences (pp. 13727-13731). Oxford: Elsevier Science. https://doi.org/10.1016/B0-08-043076-7/03187-9

Szasz, P. (2010). State of the Profession: Intensive English Programs. The CATESOL Journal 21.1:194-20. Retrieved from http://www.catesoljournal.org/wp-content/uploads/2014/06/CJ21_szasz.pdf

Ushiogi, M. (2008). Humboldt rinen no shuen?: Gendaidaigaku no sinjigen (Is the end of Humboldtian ideal?: New dimension of modern university). Tokyo: Toshindo Publishing Co.

Wang, H. X. (2009). Survey and analysis on College English Teacher and its Teaching. Foreign Language World, 4, 6-13.

Wang, S. R. (2016). Illustration on keys of Guides on College English Teaching, 2015 Foreign Language World, $3,2-10$.

Wang, W. B., \& Li, M. (2016). It's the time for creating Foreign Language Education a discipline. Guangming Paper. pp.014.

Wang, W. B., \& Li, M. (2017). A Theoretical Framework for Foreign Language Education Research: Construction and Expounding. Foreign Langauge Education, 1, 1-5.

Wang, W. B., \& Li, M. (2018). What discipline does foreign language education belong to?-The necessity to establish Foreign Language Education Studies as a discipline and its related issues. Foreign Langauge Education, 1, 44-49.

Wen, Q. F., \& Ren, Q. M. (2010). on In-service Tertiary EFL Teacher Professional Development in China: Trends, Characteristics, Problems and Solutions - by Reviewing the Related Literature From 1999 to 2009. Foreign Language in China, 4, 77-83. Retrieved from https://en.wikipedia.org/wiki/Discipline_(academia)

Williams, D., \& Coles, L. (2007). Teachers' approaches to finding and using research evidence: An information literacy perspective. Educational Research, 49(2), 185-206. Retrieved from http://dx.doi.org/10.1080/00131880701369719

Xia, J. M. (2002). A report on investigating the College English teachers' knowledge of and beliefs in foreign language education and their roles in teaching, researching and professional development. Foreign Language World, 5, 35-41.

Xin, G. Q. (2006a). Whether college English is an academic discipline in its own right? Foreign Language World, 4, 13-20. 
Xin, G. Q. (2006b). on In-service college English teachers' development. Foreign Language Teaching Abroad, 3, $20-25+56$.

Xiong, J. H. (2008). A Study on teacher professional standards: Based on the perspective of international cases (Unpublished doctoral dissertation). East China Normal University, Shanghai, China. (pp.19-20).

Ye, L. (2011). Present Situation and Enlightenment of Faculty Qualification System in the World: A Review on the International Symposium "Faculty Qualification: A Global Trend". Fudan Education Forum, 6, 89-92.

Zheng, J. (2013). Faculty qualification in the perspective of eligibilities. Education Review, 5, 57-59.

\section{Notes:}

1. Belt and Road Initiative: "The Belt and Road Initiative (BRI) is a global development strategy adopted by the Chinese government involving infrastructure development and investments in 152 countries and international organizations in Asia, Europe, Africa, the Middle East, and the Americas." (Belt and Road Initiative 2019, Oct.3). In Wikipedia, the free encyclopedia. Retrieved from https://en.wikipedia.org/wiki/Belt_and_Road_Initiative

\section{Copyrights}

Copyright for this article is retained by the author(s), with first publication rights granted to the journal.

This is an open-access article distributed under the terms and conditions of the Creative Commons Attribution license (http://creativecommons.org/licenses/by/4.0/). 